\title{
EFFECT OF PLANT GROWTH PROMOTING RHIZOBACTERIA AND SOME PLANT EXTRACTS ON ROOTABILITY OF AERIAL HAYANY DATE PALM OFFSHOOTS
}

\author{
A- ROOTING PARAMETERS AND SURVIVAL (\%)
}

\author{
Marwa M. El Taweel; M.D. El-Deeb; M.M. Sourour and H.A. El-Alakmy \\ Dept. Plant Prod., Fac. Environ. Agric. Sci., El-Arish, Suez Canal Univ.
}

\begin{abstract}
This experiment was carried out at the nursery of Faculty of Environmental and Agricultural Sciences, El-Arish, North Sinai, Egypt, to study the effect of inoculation with the plant growth promoting rhizobacteria (PGPR), i.e. Rhizobactereien $(75 \mathrm{~g} / \mathrm{l})$ or Nitrobien $(65 \mathrm{~g} / \mathrm{l})$ and the plant extracts namely : Gifert (Algae aqueous extracts), Ginger + Cinnamon extract and Roselle aqueous extract at $10 \%$ alone and in combination on the rootability and survival percentage of small high (unrooted) "Hayany" date palm (Phoenix dactylifera L.) offshoots .Results showed that, the highest rooting and survival percentages were observed with Rhizobacterien inoculated offshoots than Nitrobien inoculated ones. Moreover, treating them offshoots with Gifert (Algae extract) gave the highest values of rooting and survival percentages of small offshoots, followed by Roselle plant extract and Ginger combined with Cinnamon aqueous extract, respectively. The highest values of rooting and survival percentages were observed with Gifert (Algae extract) treated offshoots and inoculated with Rhizobacterien, while small offshoots treated with Nitrobien X Ginger and Cinnamon had the least values in this respect. The other interactions came in between them in this concern.
\end{abstract}

Key words: Date palm, rooting, plant growth promoting rhizobacteria (PGPR), Rhizobacterien, Nitrobien, plant extracts (antioxidants), Gifert (Algae extract), Roselle and Ginger + Cinnamon extract mixture.

\section{INTRODUCTION}

There is always an increased demand for date palm offshoots, especially superior cultivars. Using offshoots for propagating date palms is up till now the main method in order to insure true to type trees (AlBakr, 1972).

Problems of breeding and propagating date palm have been arised from the fact that the palm has a long life cycle (Ammar and Badeis, 1983), and that the number of offshoots produced by the mother palm is linked to a certain period in the life date palm (Barret, 1973). During recent years there is an extreme demand for date palm offshoots for cultivation. The use of small sized and aerial high offshoots is not practiced due the absence of roots and low survival percentage which lead to shy rootability. The rooting capacity (ridders) has been correlated with their endogenous promoters and carbohydrate contents (Reuveni and Adato, 1974). There are several other rooting co-factors that occur naturally in cuttings or offshoots of several plant species.

These co-factors appear to act synergistically with auxin in rooting initiation (James and Thurbon, 1981). The action of these co-factors in rooting promotion could be, at least, protecting the root induction. The rooting medium is an 
important factor in determining the extent of root formation on the offshoots (AlMana et al., 1996).

Different strains of rhizosphere bacteria, called plant growth promoting rhizobacteria (PGPR) are a heterogeneous group of bacteria that can be found in the rhizosphere at root surfaces and associate with roots to improve the extent or quality of plant growth directly and or indirectly (Gilick, 1995). The use of plant extracts that contain a lot of active compounds could be a successful alternative to chemical improving root formation on small ridder date palm offshoots (EI-Deeb et al., 2008).

Thus, this study was carried out to evaluate the effect of plant growth promoting rhizobacteria and some plant extracts on rootability and survival percentage of small ridder Hayany date palm offshoots of the treated offshoots.

\section{MATERIALS AND METHODS}

In early April of 2010/2011 seasons, 120 small ridder "Hayany" date palm offshoots (Phoenix dactylifera L.), weighing about 2.15-3 Kg with 10-17 cm in stem diameter were devoted for this study. The selected offshoots were healthy and approximately similar in size and growth vigour.

Then, the lower layer of the leaves was removed and the base of the small ridder offshoots were cleaned and submerged for ten minutes in disinfection solution containing $1 \%$ cupper sulfate $\left(\mathrm{CuSO}_{4}\right)$ at 10 g. $1^{-1}$. Each offshoot was planted in a black plastic pot $30 \mathrm{~cm}$ in diameter filled with 4 $\mathrm{kg}$ of mixture by volume of (3 sand : 2 peatmoss :1vermiculite), Each pot was inoculated with $75 \mathrm{~g}$ Rhizobacterein or $65 \mathrm{~g}$ Nitrobein, except those of the control treatment. Rhizobacterein is a mixture of Azotobacter chroococcum and Azospirillum barasilense, while Nitrobein contain Azospirillum spp and Azotobacter chroococcum. Such products are produced by the Ministry of Agric., Egypt.

The small offshoots were treated with the following plant extracts by submerging them for 24 hours before planting, and after planting they were treated with the final extracts at $100 \mathrm{ml} /$ offshoot twice a week.

\section{Gifert (Algae aqueous extract):}

At $10 \%$ by completing $100 \mathrm{ml}$ of the extract to one liter with distilled water.

\section{Ginger plus cinnamon aqueous extract:}

This extract was prepared by adding $50 \mathrm{~g}$ of powdered ginger $+50 \mathrm{~g}$ of powdered cinnamon to one litter of distilled water at $50^{\circ} \mathrm{C}$ for 24 hours, then the extract was filtrated and adjusted to one liter to obtain concentration of $10 \%(\mathrm{~W} / \mathrm{V})$.

\section{Roselle extract:}

100 grams of powdered Roselle flowers were soaked in distilled water at ${ }^{\circ} \mathrm{C}$ for 24 hours, then the extract was filtered and adjusted to one liter to obtain the concentration of $10 \%(\mathrm{~W} / \mathrm{V})$ extract.

\section{Control (tap water):}

Small ridder offshoots were watered twice weekly with tap water, the chemical analysis of tap water used in this study is presented in Table (1). The treatments were arranged as a factorial experiment in a completely randomized block design (2 factors) with three replicates for each treatment, each replicate was represented by five offshoots.

Specific and interaction effects of the investigated factors were studied through the determination of the following measurements:

\section{Survival percentage $(\%)$}

One year after treatment, offshoots growth was observed as survival percentage $(\%)$. 
Table (1): Chemical analysis of irrigation water used:

\begin{tabular}{|c|c|c|}
\hline \multicolumn{2}{|l|}{ Parameters } & Value \\
\hline \multicolumn{2}{|l|}{ E.C $\left(\mathrm{dSm}^{-1}\right)$} & 0.83 \\
\hline \multicolumn{2}{|l|}{ Conc. (ppm) } & 532 \\
\hline \multicolumn{2}{|l|}{$\mathrm{pH}$} & 8.0 \\
\hline \multicolumn{3}{|c|}{ Soluble cations (Meq. $1^{-1}$ ) } \\
\hline \multicolumn{2}{|c|}{$\mathrm{Ca}^{+2}$} & 4.0 \\
\hline \multicolumn{2}{|r|}{$\mathrm{Mg}^{+2}$} & 2.0 \\
\hline \multicolumn{2}{|r|}{$\mathrm{Na}^{+}$} & 4.5 \\
\hline & $\mathrm{K}^{+}$ & 0.1 \\
\hline \multicolumn{3}{|c|}{ Soluble anions (Meq. $1^{-1}$ ) } \\
\hline \multicolumn{2}{|r|}{$\mathrm{Cl}^{-}$} & 2.40 \\
\hline \multicolumn{2}{|r|}{$\mathrm{CO}_{3}^{-2}$} & - \\
\hline & $\mathrm{HCO}_{3}^{-}$ & 6.25 \\
\hline & $\mathrm{SO}_{4}$ & 1.95 \\
\hline \multicolumn{3}{|c|}{ Water quality $^{*}$} \\
\hline & Total salinity & $\mathrm{C} 3$ \\
\hline & Sodicity & $\mathrm{S} 1$ \\
\hline
\end{tabular}

\section{Where:}

Artesian water well from Faculty of Environmental Agricultural Science, ElArish, North Sinai Governorate, according to Piper (1947)

The survival percentage was calculated using the following equation:

\footnotetext{
Number of survived offshoots after one year Survival percentage $=$ Total number of planted offshoots
}

\section{Growth measurements}

One year after planting, the small offshoots were uprooted from the media and separated. Measurements were taken for each offshoots as survival on root formation and development. After removing survived offshoots from the medium, number and length of main roots, as well as fresh and dry weights were recorded then all the formed roots were removed and separated according to the diameter, since the secondary roots were 0.1 to $1 \mathrm{~mm}$ in diameter, while that of the main roots (above $1.3 \mathrm{~mm}$ ).

Moreover, the various types of each root were independently dried in an oven at $70^{\circ} \mathrm{C}$ for forty eight hours to determine the dry weights. The total dry weight of each offshoot root system was calculated.

\section{Statistical analysis}

The obtained data were subjected to the analysis of variance methods according to Snedecor and Cochran (1980). The means were compared using Dunca's multiple test at (0-05) level (Duncan, 1955). Computations were performed using MSTATC computer programs package (Russell, 1986). 


\section{RESULTS AND DISCUSSION}

\section{Rooting parameters}

Tables (2) and (3) show the specific effect and interaction of plant growth promoting rhizobacteria (PGPR) and plant extracts on rooting of small-aerial-Hayany date palm offshoots during the two seasons, of study.

\subsection{The total main roots fresh weight small aerial offshoot}

Referring to the specific effect of plant growth promoting rhizobacteria (PGPR)on the inoculated offshoots, data in Table (2) clear that the Rhizobacterien inoculated offshoots exhibited a significant higher effect on the total main roots fresh weight $(15.40$ and $6.80 \mathrm{~g})$ than Nitrobieninoculated ones (5.95 and $3.64 \mathrm{~g}$ ) in the first and second seasons, respectively.

Furthermore, Table 2 shows that Gifert (Algae extract) treatment recorded the highest fresh weight of total main roots (36.74 and $13.56 \mathrm{~g}$ ), followed by Roselle ( 3.15 and $3.58 \mathrm{~g})$ and Ginger + Cinnamon aqueous extracts (1.67 and $1.97 \mathrm{~g})$ in the first and second seasons, respectively with significant differences between them compared with untreated offshoots (control) which recorded the least values (1.15 and $1.20 \mathrm{~g})$ in the two seasons.

Regarding the interaction between plant growth promoting rhizobacteria (PGPR) and the testing plant extracts on rooting of small aerial "Hayany" date palm offshoots. Table (2) reveals that Rhizobacterieninoculated offshoots and treated with Gifert (Algae extract) had the highest values for total fresh weight of main roots (55.1 and $17.87 \mathrm{~g})$ followed by Rhizobacterien inoculated offshoots while the least values $(1.06$ and $1.10 \mathrm{~g})$ were recorded for untreated offshoots (control).

Other interactions came among them with significant differences in this respect in both seasons.

\subsection{The total main roots dry weight}

Data in Table (2) disclose that total main roots dry weight was significantly increased by Rhizobacterien inoculated offshoots than those inoculated with Nitrobien.

Table (2) reveal also that Gifert (Algae extract) gained the highest values of total main roots dry weight per small aerial offshoots (15.22 and $6.74 \mathrm{~g}$ ), followed by Roselle extract then Ginger + Cinnamon extract treatments, while untreated offshoots (control) showed the least values $(1.83$ and $0.75 \mathrm{~g})$ in first and second seasons, respectively.

The interaction between plant growth promoting rhizobacteria (PGPR) and plant extracts (antioxidants) on rooting offshoots, showed that the inoculated offshoots with Rhizobacterien combined with Gifert (Algae extract) values induced the highest main roots dry weight, followed by Gifert (Algae extract) Nitrobien inocwulated offshoots.

While the untreated offshoots (control) recorded the least main roots dry weight $(0.73$ and $0.80 \mathrm{~g})$ in both seasons, respectively. These results go in line with those reported by Janzen et al. (1992), Holguin et al. (1999), Salamone et al. (2001), Zahir et al. (2001), Salmeron et al. (2003), Vessey (2003) and Zahir et al. (2003).

\subsection{Number of main root per small- aerial of fshoot}

The Rhizobacterien inoculated offshoots exhibited a significant higher number of main roots (5.28 and 3.50 roots/offshoot) than Nitrobien inoculated ones (3.0 and 2.09 roots/ offshoot) in the first and second seasons, respectively (Table 2 ).

Furthermore, Table, 2 shows that the most obvious increments in the number of main roots/offshoot observed with Gifert (Algae extract) (12.16 and 6.33) roots/ offshoot followed by Roselle (1.83 and 1.78) 
SINAI Journal of Applied Sciences (ISSN: 2314-6079) Vol. (4) Is. (3), Dec. 2015

Table (2): Effect of plant growth promoting rhizobacteria and some aqueous plant extracts of on No of main roots/offshoot, fresh and dry weight of main roots of small aerial offshoots of 'Hayany' date palm during 2010/11 and 2011/12 seasons.

\begin{tabular}{|c|c|c|c|c|c|c|c|c|c|}
\hline \multirow{2}{*}{$\overbrace{\text { plant extracts }}^{\text {PGPR }}$} & \multicolumn{3}{|c|}{$\begin{array}{l}\text { No .of main } \\
\text { roots/offshoot }\end{array}$} & \multicolumn{3}{|c|}{ Fresh weight (g) } & \multicolumn{3}{|c|}{ Dry weight (g) } \\
\hline & Rhizo. & Nitro. & Mean & Rhizo. & Nitro. & Mean & Rhizo. & Nitro. & Mean \\
\hline \multicolumn{10}{|c|}{ First season $(2010 / 2011)$} \\
\hline Control (tap water) & $1.45 \mathrm{c}$ & $1.14 \mathrm{c}$ & $1.29 \mathrm{c}$ & $1.23 \mathrm{~d}$ & $1.06 \mathrm{~d}$ & $1.15 \mathrm{c}$ & $0.73 \mathrm{e}$ & $1.10 \mathrm{e}$ & $1.83 \mathrm{c}$ \\
\hline $\begin{array}{l}\text { Gifert } \\
\text { (Algae extract) }\end{array}$ & $16.33 \mathrm{a}$ & $8.00 \mathrm{~b}$ & $12.16 \mathrm{a}$ & $55.10 \mathrm{a}$ & $18.37 \mathrm{~b}$ & $36.74 \mathrm{a}$ & $21.17 \mathrm{a}$ & $9.27 \mathrm{~b}$ & $15.22 \mathrm{a}$ \\
\hline $\begin{array}{l}\text { Roselle } \\
\text { (aqueous extract) }\end{array}$ & $2.00 \mathrm{~b}$ & $1.66 \mathrm{c}$ & $1.83 \mathrm{~b}$ & $3.50 \mathrm{c}$ & $2.80 \mathrm{c}$ & $3.15 \mathrm{~b}$ & $5.13 \mathrm{c}$ & $2.20 \mathrm{~d}$ & $3.66 \mathrm{~b}$ \\
\hline $\begin{array}{l}\text { Ginger+Cinnamon } \\
\text { (aqueous extract) }\end{array}$ & $1.32 \mathrm{~d}$ & $1.20 \mathrm{c}$ & $1.26 \mathrm{c}$ & $1.77 \mathrm{~d}$ & $1.57 \mathrm{~d}$ & $1.67 \mathrm{c}$ & $2.90 \mathrm{~d}$ & $1.83 \mathrm{~d} 2$ & $2.37 \mathrm{bc}$ \\
\hline Mean & $5.28 \mathrm{c}$ & $3.00 \mathrm{~d}$ & & $15.40 \mathrm{a}$ & 5.95 bc & & $7.39 \mathrm{~b}$ & $3.59 \mathrm{c}$ & \\
\hline \multicolumn{10}{|c|}{ Second season (2011/2012) } \\
\hline Control (tap water) & $1.35 \mathrm{c}$ & $1.12 \mathrm{c}$ & $1.24 \mathrm{c}$ & $1.3 \mathrm{~d}$ & $1.1 \mathrm{~d}$ & $1.20 \mathrm{~d}$ & $0.97 \mathrm{e}$ & $0.80 \mathrm{e}$ & $0.75 \mathrm{~d}$ \\
\hline $\begin{array}{l}\text { Gifert } \\
\text { (Algae extract) }\end{array}$ & $8.33 \mathrm{a}$ & $4.33 \mathrm{~b}$ & $6.33 \mathrm{a}$ & $17.87 \mathrm{a}$ & $9.43 \mathrm{~b}$ & $13.56 \mathrm{a}$ & $9.42 \mathrm{a}$ & $4.60 \mathrm{~b}$ & $6.74 \mathrm{a}$ \\
\hline $\begin{array}{l}\text { Roselle } \\
\text { (aqueous extract) }\end{array}$ & $2.00 \mathrm{c}$ & $1.56 \mathrm{c}$ & $1.78 \mathrm{c}$ & $5.13 \mathrm{c}$ & $2.2 \mathrm{~d}$ & $3.58 \mathrm{c}$ & $2.37 \mathrm{c}$ & $1.13 \mathrm{~d}$ & $1.75 \mathrm{c}$ \\
\hline $\begin{array}{l}\text { Ginger+Cinnamon } \\
\text { (aqueous extract) }\end{array}$ & $2.33 \mathrm{bc}$ & $1.33 \mathrm{c}$ & $1.83 \mathrm{c}$ & $2.9 \mathrm{~d}$ & $1.83 \mathrm{~d}$ & $1.97 \mathrm{~d}$ & $1.67 \mathrm{~cd}$ & $1.40 \mathrm{~d}$ & $1.85 \mathrm{c}$ \\
\hline Mean & $3.50 \mathrm{~b}$ & $2.09 \mathrm{~b}$ & & $6.80 \mathrm{~b}$ & $3.64 \mathrm{c}$ & & $3.60 \mathrm{~b}$ & $1.98 \mathrm{c}$ & \\
\hline
\end{tabular}

Means followed by the same letter(s) within each column are not significantly different at the 0.05 level, according to Duncan's multiple range test.

roots/ offshoot against untreated offshoots (control) (1.29 and 1.24) roots/ offshoot in first and second seasons, respectively. On the other hand, the other treatments came in between in this respect. Disclosed data showed that the highest number of main roots per offshoots was resulted from inoculated offshoots with Rhizobacterien $\times$ Gifert (Algae extract) treatment followed by Gifert provided with Nitrobien inoculated offshoots. The least values were recorded by untreated offshoots (control).

The other interactions came in between with significant difference among them. This increment of number of main roots numbers may be due to the promotion effect of (PGPR) and plant extracts, which greatly affect root development. Similar results were reported earlier by Rizk and El-Sayed (2004).

\subsection{Fresh weight of Total roots}

Data in Table (3) show that total fresh weight of root system of the inoculated offshoots with Rhizobacterien was greater than that with inoculated Nitrobien ones in both seasons.

In reference to the effect of plant extracts, results showed that the untreated offshoots (control), significantly gained the 
Table (3): Effect of plant growth promoting rhizobacteria and aqueous plant extracts on total root system and the length of the longest main root of small aerial of 'Hayany' date palm offshoots during 2010/2011 and 2011/2012 seasons.

\begin{tabular}{|c|c|c|c|c|c|c|c|c|c|}
\hline \multirow{2}{*}{$\overbrace{\text { plant extracts }}$ PGRP } & \multicolumn{3}{|c|}{ Fresh weight (g) } & \multicolumn{3}{|c|}{ Dry weight (g) } & \multicolumn{3}{|c|}{ Length(mm) } \\
\hline & Rhizo. & Nitro. & Mean & Rhizo. & Nitro. & Mean & Rhizo. & Nitro. & Mean \\
\hline \multicolumn{10}{|c|}{ First season $(2010 / 2011)$} \\
\hline Control (tap water) & $3.10 \mathrm{e}$ & $1.90 \mathrm{e}$ & $2.50 \mathrm{e}$ & $1.86 \mathrm{e}$ & $1.50 \mathrm{e}$ & $1.68 \mathrm{~d}$ & $2.57 \mathrm{~d}$ & $1.57 \mathrm{c}$ & $2.07 \mathrm{~d}$ \\
\hline $\begin{array}{l}\text { Gifert } \\
\text { (Algae extract) }\end{array}$ & $72.17 \mathrm{a}$ & $29.63 \mathrm{~b}$ & $50.90 \mathrm{a}$ & $32.0 \mathrm{a}$ & $16.13 \mathrm{~b}$ & 24.11 a & $92.50 \mathrm{a}$ & $20.17 \mathrm{~b}$ & 56.34 a \\
\hline $\begin{array}{l}\text { Roselle } \\
\text { (aqueous extract) }\end{array}$ & $12.93 \mathrm{c}$ & $8.93 \mathrm{~d}$ & $10.93 \mathrm{c}$ & $7.77 \mathrm{c}$ & $4.93 \mathrm{~d}$ & $6.35 \mathrm{c}$ & $22.17 \mathrm{~b}$ & $12.03 \mathrm{bc}$ & $17.10 \mathrm{~b}$ \\
\hline $\begin{array}{l}\text { Ginger+Cinnamon } \\
\text { (aqueous extract) }\end{array}$ & $7.73 \mathrm{~d}$ & $6.50 \mathrm{~d}$ & $7.12 \mathrm{~d}$ & $3.97 \mathrm{~d}$ & $3.03 \mathrm{~d}$ & $3.50 \mathrm{~cd}$ & $7.98 \mathrm{c}$ & $9.83 \mathrm{~cd}$ & $8.90 \mathrm{c}$ \\
\hline Mean & $23.98 \mathrm{~b}$ & $11.74 \mathrm{c}$ & & $11.40 \mathrm{~b}$ & $6.41 \mathrm{c}$ & & $31.31 \mathrm{bc}$ & $10.9 \mathrm{c}$ & \\
\hline \multicolumn{10}{|c|}{ Second season $\quad(2011 / 2012)$} \\
\hline Control (tap water) & $3.90 \mathrm{e}$ & $1.76 \mathrm{e}$ & $10.75 \mathrm{c}$ & $1.97 \mathrm{~d}$ & $1.2 \mathrm{~d}$ & $1.62 \mathrm{~d}$ & $2.89 \mathrm{~d}$ & $1.97 \mathrm{~d}$ & $2.43 \mathrm{~d}$ \\
\hline $\begin{array}{l}\text { Gifert } \\
\text { (Algae extract) }\end{array}$ & $29.63 \mathrm{a}$ & $19.2 \mathrm{~b}$ & 24.42 a & $14.97 \mathrm{a}$ & $8.34 \mathrm{~b}$ & $11.71 \mathrm{a}$ & $21.57 \mathrm{a}$ & $12.77 \mathrm{~b}$ & $17.17 \mathrm{a}$ \\
\hline $\begin{array}{l}\text { Roselle } \\
\text { (aqueous extract) }\end{array}$ & $13.47 \mathrm{c}$ & $8.74 \mathrm{~d}$ & $8.71 \mathrm{~d}$ & $6.23 \mathrm{~b}$ & $4.90 \mathrm{c}$ & $5.61 \mathrm{~b}$ & $13.20 \mathrm{~b}$ & $7.77 \mathrm{c}$ & $10.49 \mathrm{~b}$ \\
\hline $\begin{array}{l}\text { Ginger+Cinnamon } \\
\text { (aqueous extract) }\end{array}$ & $8.03 \mathrm{~d}$ & $6.50 \mathrm{~d}$ & $7.31 \mathrm{~d}$ & $4.63 \mathrm{c}$ & $3.47 \mathrm{c}$ & $2.03 \mathrm{c}$ & $2.16 \mathrm{c}$ & $3.64 \mathrm{~d}$ & $2.90 \mathrm{~d}$ \\
\hline Mean & $13.76 \mathrm{~b}$ & $9.05 \mathrm{~d}$ & & $6.95 \mathrm{c}$ & $4.47 \mathrm{~d}$ & & $9.95 \mathrm{~b}$ & $6.54 \mathrm{c}$ & \\
\hline
\end{tabular}

Means followed by the same letter(s) within each column are not significantly different at the 0.05 level, according to Duncan's multiple range test.

Rhizo $=$ Rhizobacteria and Nitro $=$ Nitrobien

lowest total root system fresh weight in both seasons, while Gifert (Algae extract) recorded the highest total root fresh weight.

The other treatments came in between. Similar observations were reported by AlObeed (2005).

\subsection{Dry weight of total roots and the length of the longest main root}

Data in Table (3) clear that the Rhizobacterien inoculated offshoots, significantly increased total dry weight of root system and produced the longest main root than Nitrobien inoculated offshoots. The same results were found by Shaban and Mohsen (2009).

As for the effect of plant extracts, data in the same Table show that Gifert (Algae extract) caused a significant increase in total dry weight of root system and produced the longest main root followed by Roselle aqueous extract then Ginger + Cinnamon aqueous extract. The least values in this respect were recorded for the untreated offshoots.

Regarding the interaction between plant growth promoting rhizobacteria (PGPR) and aqueous plant extracts, data in Table (3) indicated that the heaviest root system dry weight and the longest main roots were gained by the inoculated offshoots with Rhizobacterien combine with Gifert (Algae extract) (Fig. 1). While the least values were recorded py untreated offshoots (control). The other interactions came in between with significant differences between them. These results go in line with 
SINAI Journal of Applied Sciences (ISSN: 2314-6079) Vol. (4) Is. (3), Dec. 2015

those reported by El Hodairi, et al. (1992)

Wange and Ranawade (1998) and Rizk and El Sayed (2002).

Generally, the root formation will proceed according to a genetically determined pattern as modified by each of chemical, physical and bio-environmental factors. Among physical factors the plant growth promoting rhizobacteria (PGPR) and plant extracts which greatly affect both root development and distribution patterns.

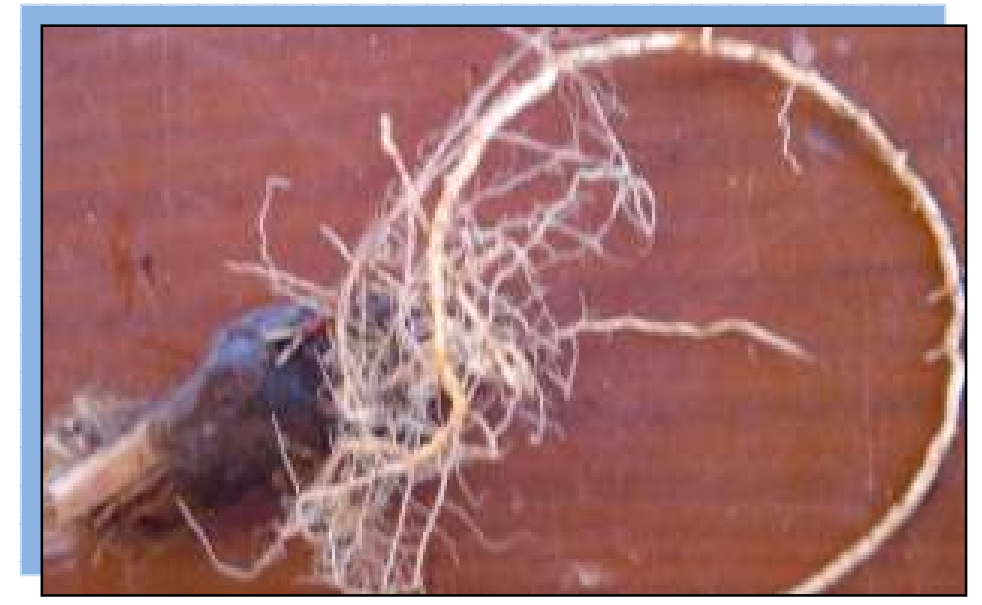

Fig. (1): Gifert (Algae extract) $\times$ Rhizobacterien inoculation treatment induced the longest main roots.

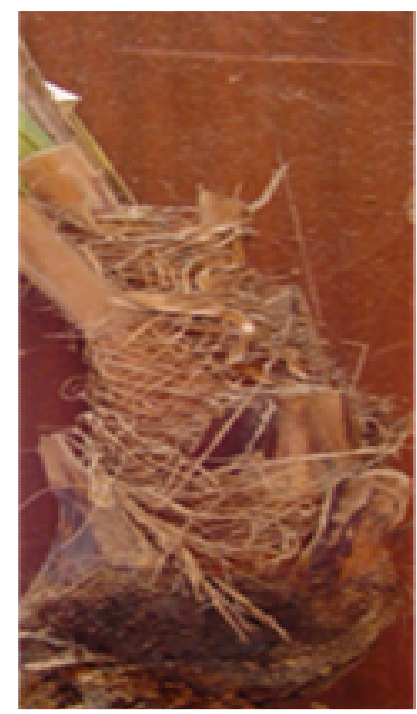

(2)

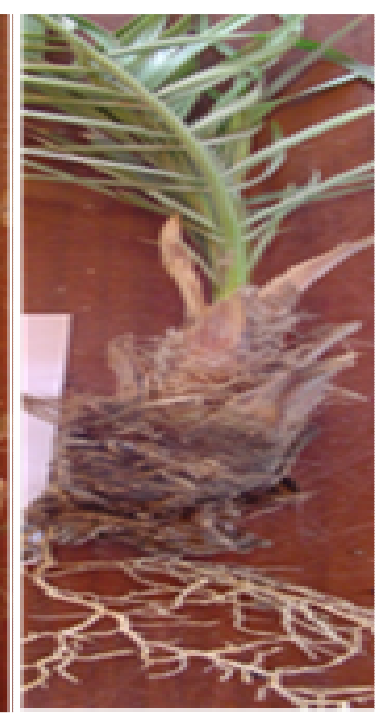

(3)

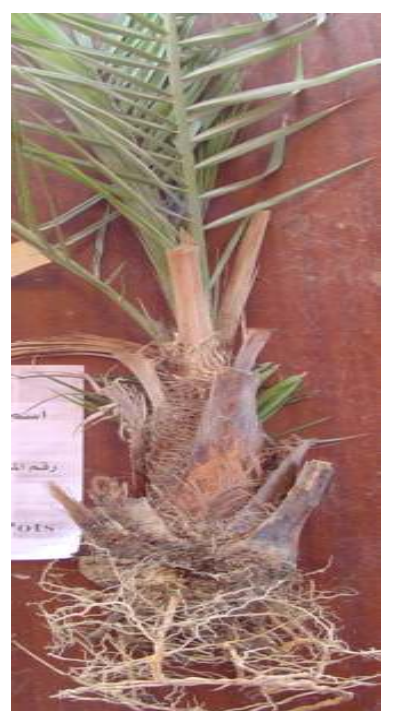

(4)

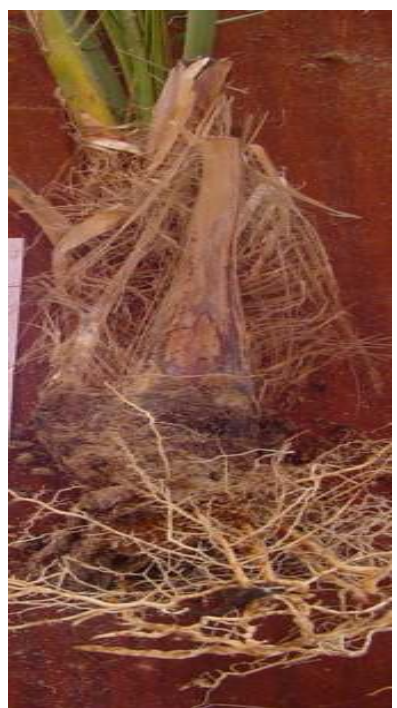

(5)

Fig . (2): Unrooted in control treatment.

Fig. (3): Offshoots roots in Ginger + Cinnamon (aqueous extract) $\times$ Rhizobacterien treatment, Fig . (4): Offshoots roots in Roselle (aqueous extract) $\times$ Rhizobacterien treatment

Fig . (5): Offshoots roots in Gifert (Algae extract) $\times$ Rhizobacterien treatment. 
All treatments induced drastic modifications in the hormonal patterns at the different stages of root formation. On the other hand, the cut surface of the offshoots (the attachment point with the mother palm) is accompanied by secretion of some substances into the medium, such as phenols, may have profound physiological effect on the cultured offshoots. These results are in line with those reported by ElHamady et al. (1992) and Hodel and Pitteger (2003).

On the other hand, browning of the tissue and adjacent medium is assumed to be due to the ordination of polyphenoles and formation of quinines which are aerial reactive and toxic to the tissues.

Aside from, several enzymes which are widely distributed in plant oxides phenols to quinines e.g., monophenol oxidase (tyrosinase and polyphynol oxidase (catchall oxidase). Furthermore, adding Gifert (Algae extract), Roselle and Ginger + Cinnamon aqueous extracts plus the plant growth promoting rhizobacteria (PGPR) (Rhizobacterien or/and Nitrobien) for curtailing the oxidations of the phenolic compounds.

In other words, using plant growth promoting rhizobacteria (PGPR) may prevent or minimize releasing and oxidation of endogenous phenolic compounds, which included either through antioxidant or absorbent substance. Al-Mana et al. (1996), Sourour (2001), Okawara et al. (2003), Qaddoury and Amssa (2003) ,Vezvaei, et al. (2003), Rizk and El sayed (2004) Qaddoury and Amssa (2004), ElAssar et al. (2004)and Al-Obeed (2005).

\section{Survival percentage (\%)}

Concerning the effect of plant growth promoting rhizobacteria (PGPR) Fig. (6) show that the Rhizobacterien inoculated offshoots gave the highest surviving percentage than the Nitrobien inoculated ones in the first season. But, in the second one the survival percentages were similar for both Rhizobacterien and Nitrobien inoculated offshoots.

As for the effect of plant extracts, Fig. (7) clear that all tested plant extracts caused a significant increase in the survival percentage of small aerial offshoots than untreated ones (control). The highest survival percentage was recorded for Gifert (Algae extract) treatment, followed by Roselle aqueous extract, Ginger + Cinnamon aqueous extract treatments, respectively.

In relation to the interaction between plant growth promoting rhizobacteria (PGPR) and plant extracts, Fig. (8) clear that inoculated offshoots with Rhizobacterien and those inoculated with Nitrobien which treated by Gifert (Algae extract) induced the highest simulative effect in survival percentage, while untreated offshoots (control) had the least values in this respect. The other interactions came in between with significant differences among them. Similar observations were reported by Al Ghamdi (1988), Nagarajan et al. (1989) Kloepper and Beauchamp (1992) Al Mana et al. (1996) Haggag and Azzazy (1996). El Bahr et al. (2003) and Hodel and Pittenger (2003) and Generally, it was concluded that the application of synergists of antioxidant to the medium may be enable to promote the establishment of planted offshoots and increased the percentage of survival. This results are similar with Gupta and Godara (1984), Sourour (2001), El Deeb et al. (2008), Bakr et al. (2010), Shaban and Mohsen (2009)and El Kosary (2009). 


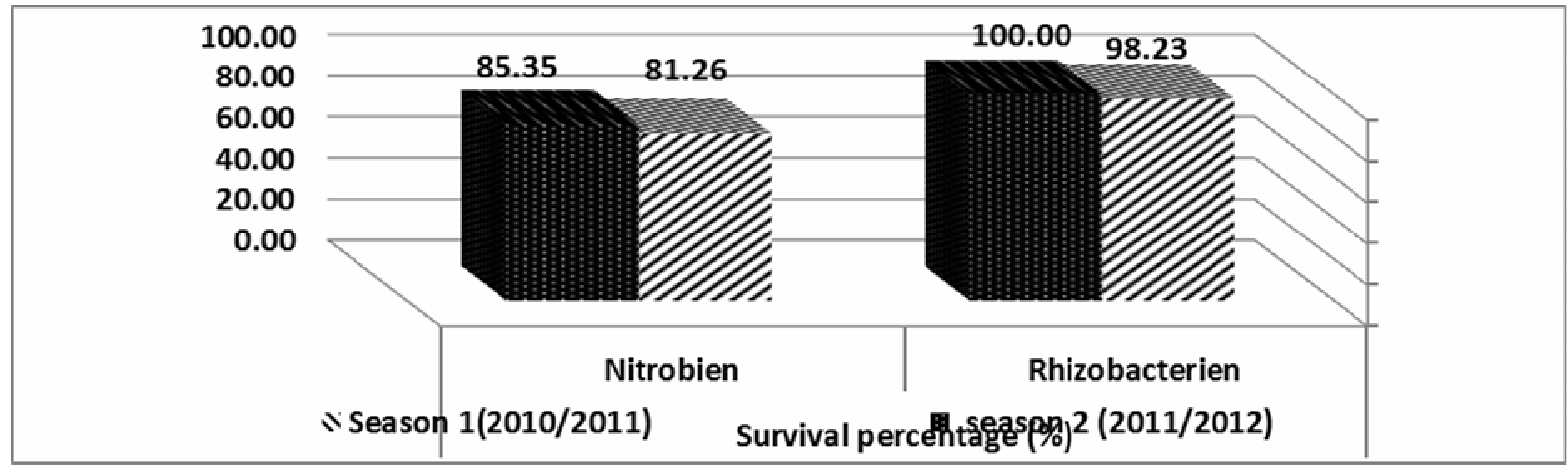

Fig. (6)

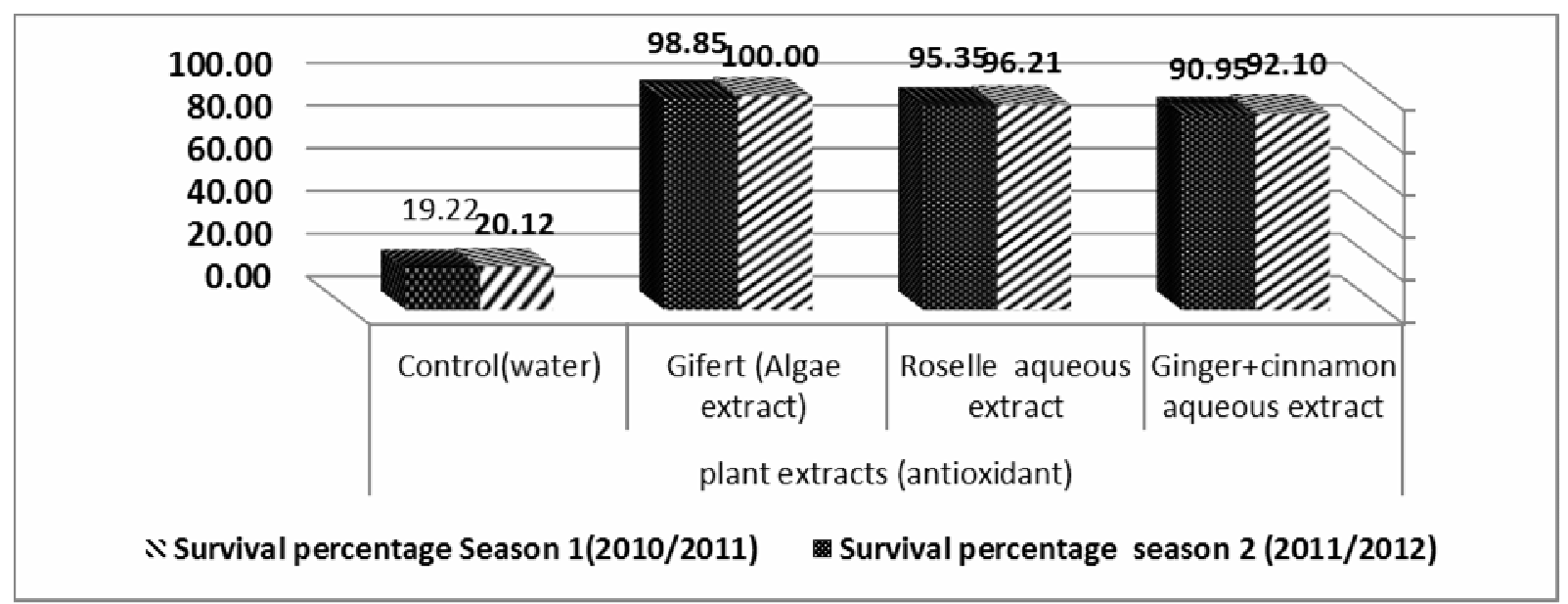

Figs. (6\&7): Specific effect of plant growth promoting rhizobacteria and (6) plant extracts and (7) on survival percentage of aerial offshoot during 2010/2011 and 2011/2012 seasons.

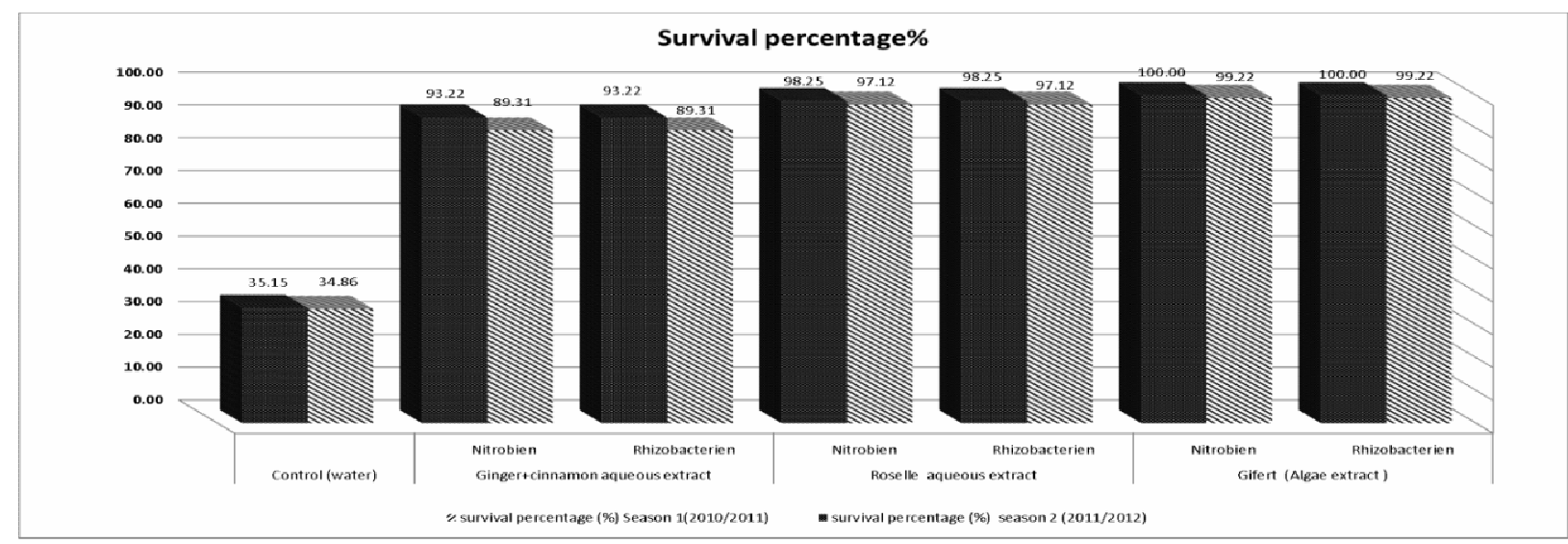

Fig. (8): Interaction effect between plant growth promoting rhizobacteria (PGPR) and plant extracts on survival percentage (\%) during 2010/2011 and 2011/2012 seasons. 


\section{REFERENCES}

Al-Bakr, A.J. (1972). The Date palm: Past ,Present and Future, $2^{\text {nd }}$ Ed., Al-Watten Press. Baghdad, Iraq.

Al-Ghamdi, A.S. (1988). Rooting of date palm offshoots as affected by offshoot size. cultivar and indole butyric acid injection. Acta, Hort., 226 (I): 379-388.

Al-Mana, F.A.; M.A. El-Hamady; M.A. Bacha and A.O. Abd El Rahman (1996). Improving root development on ground and aerial date palm offshoots. Principles, 40(4). 179-181, 217-219.

Al-Obeed, R.S. (2005). Rooting of aerial offshoots of four date palm (Phoenix dactylifera L.) cultivars by air layering method using polyethylene bages. Pak. biological .Sci., 8 (7): 978-981.

Ammar, S. and A.A.B. Badeis (1983). Vegetative propagation of date palm (Phoenix dactylifera L.) by in vitro culture. Proceedings of the First Symposium on the Date palm in Saudi Arabia, 158-166.

Bakr, E.I.; M.M.G. Haseeb; S.E. ElKosary and M.A.M. Bakir (2010). Using date palm suckers as material for vegetative propagation by growth regulators injection. Bulletin of Faculty of Agric. Cairo Univ., 61 (1): 63-78.

Barret, M.C. (1973). Date breeding and improvement in North America. Fruit Var. J., 27:50-55.

Duncan, B.D. (1955).Multiple Range and Multiple F-tests.Biometrics, 11:1-42.

El-Assar, A.M.; W.M.E. Messeih and M.R. El-Shenawi (2004). Applying some natural extracts and growth regulators to culture media and their effects on "Sewi" cv. date palm tissues grown in vitro. Assuit Journal of Agric. Sci., 35 (4): 155-168.

El-Bahr, M.K.; H.S. Taha and S.A. Bekheet (2003). In vitro propagation of
Egyptian Date palm c.v. "Zaghlool". 1In vitro rooting and in vivo acclimatization. Arab Univ. J. Agric. Sci., Ain Shams Univ., Cairo, 11 (2): 689-699.

El-Deeb, M.D.; M.M. Sourour and M.M. Marwa (2008). Vegetative propagation of date palm (Phoenix dactylifera L.) by rooting small off shoots. Environmental andAgricultural Sciences, Suez Canal University, The third International Conference on Date Palm, 13 (2) : 2025/4.

El-Hamady, M.M.; F.A. Al-Maha and M.A. Bacha (1992). Greenhouse rooting of date palm offshoots using an inverted mist system. Annals of Agricultural Science, Cairo, 37(2): 523-530.

El-Hodairi, M.H.; A.S. El-Fagih and A.A. Amer (1992). The effects of indole acetic acid, indole butyric acid (IBA) and naphthalene acetic acid (NAA) on the growth of Taaghiyaat date palm (Phoenix dactylifera L.). Acta, Horticulture, (321): 326-333.

El-Kosary, S. (2009). Optimizing date palm aerial offshoots avail through vegetative propagation. J. Agric. Sci. Mansoura Univ., 34 (4): 2553-2565.

Gilick, B.R. (1995). The enhancement of plant growth by free-living bacteria. Can. J. Microbiol., 41: 109-117.

Gupta, O.P. and N.R. Godara (1984). Rooting in aerial suckers of date palm, Haryana, Agricultural, University, Journal of Research, 14 (1): 82-84.

Haggag, L.F. and M.A. Azzazy (1996). Evaluation of microbein as a multistrains fertilizer for produced of improved mango seedlings with appropriate vigour for grafting in shorter time. Annuls of Agricultural Science. Cairo, 41(1): 321-331.

Hodel, D.R. and D.R. Pitteger (2003-b). Studies on the establishment of date 
palm (Phoenix dactylifera Deglet Noor') offshoots. Part II palms; 47(4): 201-205.

Holguin, G.; C.L. Patten and B.R. Gliek (1999). Genetics and molecular biology of Azospirillum. Biol. Fertil Soils J., 29: 10-23.

James, D.J. and I.J. Thurbon (1981). Phenolic compounds and other factors controlling rhizogenesis 'in vitro' in the apple rootstocks M.9 and M.26.

Janzen, R.A.; S.B. Rood; J.F. Dormaar and W.B. McGill (1992). Azospirillum brasilense produces gibberellin in pure culture on chemically-defined medium and in co-culture on straw. Soil Biology and Biochemistry, 24 (10): 1061-1064.

Kloepper, J.W. and C.J. Beauchamp (1992). A review of issues related to measuring colonization of plant roots by bacteria. Cana. J. of Microbiol., 38(12): 1219-1232.

Nagarajan, P.; N.V. Radha; D. Kandadamy; G. Oblisame and S. Jayaraj (1989). Effect of combined inoulation with Azosplzillum brasilense and Glomus fascicalatum an mulberry. Madras Acpic. J.1, 6(11): 601-605.

Okawara, R.; R.M. Macawi; S. AlKhateeb and T. Ohmara (2003). Improving of the initial growth of young Date palm (Phoenix dactylifera L.) plants by the application of isoprothiolane to soil, Soil, Sci. and plant Nut., 49 (2): 281-283.

Piper, C.S. (1947). Soil and Plant Analysis. The University of Adelaide (Australia), 59-74.

Qaddoury, A. and M. Amssa (2003). Impact of indole butyric acid on the rooting capacity of young date palm offshoots. Acta, Botanica Gallica; 150 (2): 213-222.

Qaddoury, A. and M. Amssa (2004). Effect of exogenous indole butyric acid on root formation and peroxidase and indole-3-acetic acid oxidase activities and phenolic contents in Date palm offshoots. Botanical Bull. Acad. Sci., 45 (2): 127-131.

Reuveni, O. and I. Adato (1974). Endogenous carbohydrates, root promoters and root inhibitors in easy and difficult to root date palm (Phoenix dactylifera L.) offshoots. J. Ame. Soc. Hort. Sci., 99: 361-363.

Rizk, S.A. and O.M. El-Sayed (2004). Physiological studies on rooting ability of offshoots of some date palm cultivars. Egyptian S. Desert Res., 54 (1):177-185.

Russell, D.F. (1986). MSTATC Director, Crop and Soil Sciences Department, Michigan State University, Computer Program Package Version 2.10

Salamone, I.E.G.; R.K. Hynes and L.M. Nelson (2001). Cytokinin production by plant growth promoting rhizobacteria and selected mutants. Can. J. of Microbiol., 47(5): 404-411.

Salmeron, V.; M.V. Martinez and J.G. Lopez (2003). Nitrogen fixation and production of auxins, gibberellins and cytokinins by an Azetobacter chroococcum strain isolated from the root of Zea mays in the presence of insoluble phophate. Chemosphere J., 20 (3-4): 417-422.

Shaban, A.E.A. and A.T. Mohsen (2009). Response of citrus rootstocks and transplants to biofertilizers. J. of Hort. Sci. and ornam. Plants, 1 (2): 39-48.

Snedecor, G.W. and W.G. Cochran (1980). Statistical Methods. Oxford and J. B. H. Publishing Co., $6^{\text {th }}$ Ed. Press Ames; Iowa U SA, 593.

Sourour, M.M. (2001) Rooting ground and aerial offshoots of three date palm cultivars grown in North Sinai using IBA and NAA compounds .J. Adv. Agric. Res., 6 (4): 883-901 
Vessey, J.K. (2003). Plant growth promoting rhizobacteria as biofertilizers. Plant and Soil J., 255 (2): 571-586.

\section{Vezvaei, A.; M. Alamdari; M.S.S. Panahi} and M. Kashai (2003). Effect of different growing media and plant growth substances on vegetative characters and offshoot production of "'Barhi" date palm liners derived from micro propagation, Iraian, J. Agri. Sci., 34 (4): 969-976.
Wange, S.S. and D.B. Ranawade (1998). Effect of microbial wiocalants on fresh root development of grape cv. Kishmis Chorone. Recent Hort., 4: 27-31.

Zahir, Z.A.; H.N. Asghar and M. Arshad (2001). Cytokinin and its precursors for improving growth and yield of rice. Soil Biol. and Biochem. J., 33 (3): 405-408.

Zahir, A.Z.; M. Arshad and W.T. Frankenberger (2003). Plant Growth Promoting Rhizobacteria: Applications and Prespectives. In Agric. Adv. in Agron. J., 81: 97-168.

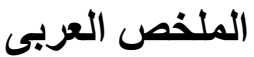

\section{تأثير بكتريا الريزوسفير المحفزة لنمو التبات وبعض المستخلصات التباتية على المقدرة التجذرية لفسائل نخيل البلح الهوائية (الرواكب) للصنف البهن الحياني

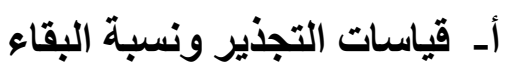

مروة مسلم الطويل ـ محمد دياب الايب ـ محمد محمود سرور ـ هاني عبد الله العلاقمي

قسم الإنتاج النباتي، كلية العلوم الزر اعية البيئية بالعريش، جامعة قناة السويس

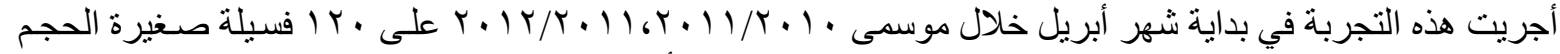

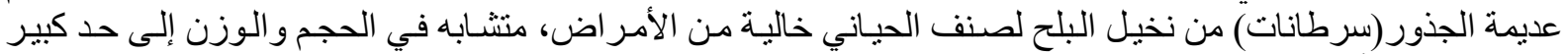

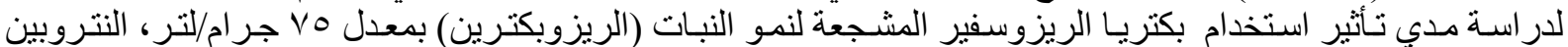

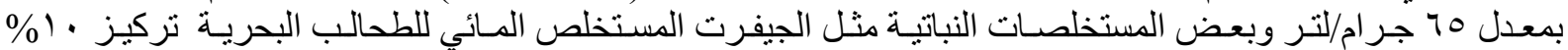

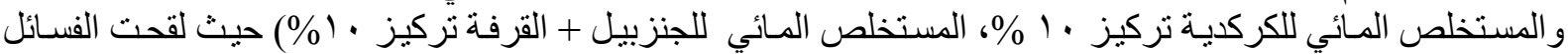

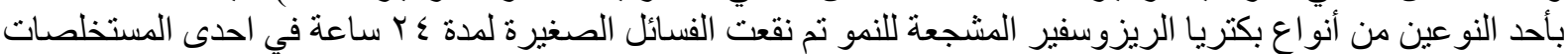

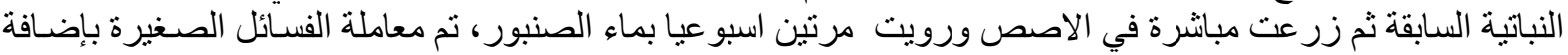

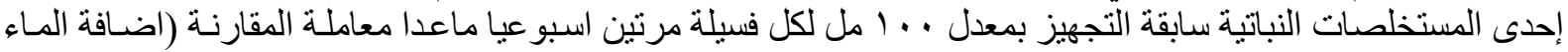

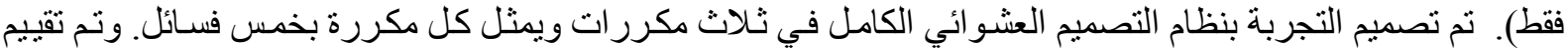
التأثير النوعي لكل العوامل المختبرة و التفاعل بينها بعد مرور عام على زر اعتها.

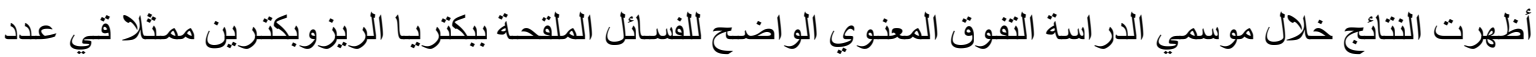

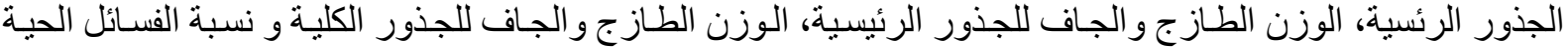

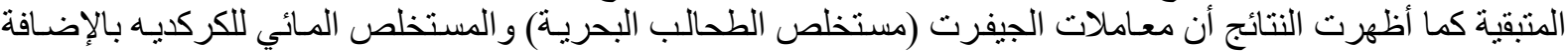

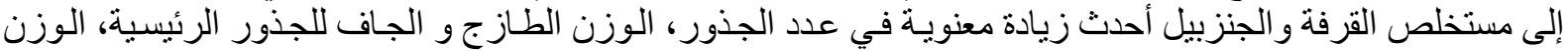

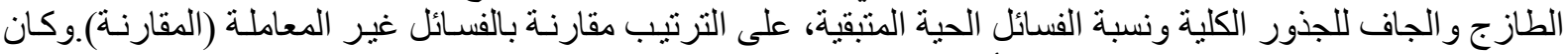

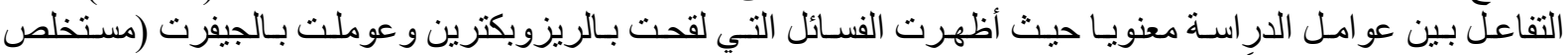

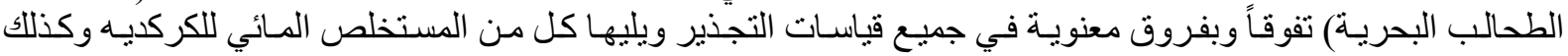

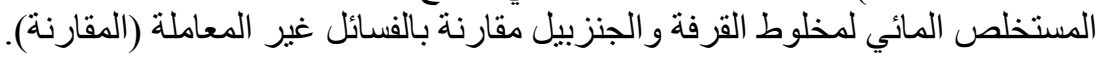
الكلمات الاسترشادية: نخيل البلح، مرحلة التجذير، بكتريا الريزوسفير، مستخلص الكركدية و القرفة. 